Henryk Dzwonkowski

\title{
W sprawie transpozycji art. 168 lit. a dyrektywy 2006/112/WE Rady do ustawy o podatku od towarów i usług ${ }^{1}$
}

Evaluation of the proposal to amend the VAT Act as regards the right to reduce the amount of tax due: The evaluated petition applies to including in the act the right to reduce the amount of tax due by the amount of the calculated tax, in particular a different regulation concerning of the time limit, in which the right to reduce the amount of tax due by the amount of the calculated tax is executable. According to the author, the request to amend such provisions may be inconsistent with provisions of the VAT Directive. The current transposition of the Directive's provisions into the Polish tax system is not defective.

Keywords: petition, Value Added tax

Słowa kluczowe: petycja, podatek VAT

Doktor hab. nauk prawnych, profesor UŁ, Wydział Prawa i Administracji Uniwersytetu Łódzkiego, ekspert ds. legislacji BAS - hdzwonkowski@poltax.pl •

https://orcid.org/0000-0002-7110-3029

\section{Treść i cel petycji}

Przedmiotem petycji XY (dalej: Pytającego, Wnioskodawcy) jest zmiana ustawy z 11 marca 2004 r. o podatku od towarów i usług (t.j. Dz.U. 2018, poz. 2174, ze zm.; dalej: u.p.t.u.) w zakresie prawa do obniżenia kwoty podatku należnego o kwotę podatku naliczonego, w szczególności odmiennego uregulowania terminu, w jakim prawo do obniżenia kwoty podatku należnego o kwotę podatku naliczonego powinno przysługiwać.

W uzasadnieniu swojej petycji Wnioskodawca wskazuje, że jego zdaniem obowiązujące przepisy ustawy polskiej, w szczególności art. 86 ust. 2 pkt 1 u.p.t.u.,

Opinia dotyczaca petycji XY w sprawie transpozycji art. 168 lit. a Dyrektywy 2006/112/ WE RADY do ustawy o podatku od towarów i ustug sporządzona 18 lutego 2019 r. na zlecenie przewodniczącego Komisji do Spraw Petycji; BAS-WASiE 170/19. 
są niezgodne z treścią art. 168 lit. a dyrektywy Rady 2006/112/WE z 28 listopada 2006 r. w sprawie wspólnego systemu podatku od wartości dodanej (Dz.Urz. UE L 347 z 2006 r., s. 1, ze. zm.; dalej: dyrektywa VAT).

Petycja zawiera propozycję treści nowego artykułu w ustawie o podatku od towarów i usług (art. 86 ust. 2 pkt 1) wraz z uzasadnieniem zmiany.

\section{Czy petycja mieści się w zakresie zadań i kompetencji adresata petycji (art. 2 ust. 3 ustawy o petycjach)?}

Petycja będąca przedmiotem niniejszej opinii obejmuje żądanie zmiany przepisów prawa o randze ustawy. Petycja mieści się w zakresie zadań i kompetencji Sejmu.

\section{Wymogi formalne (art. 4 ust. 1 i 2 oraz art. 5 ust. 1 ustawy o petycjach)}

Petycja spełnia wymogi formalne określone w art. 4 ust. 1 i 2 ustawy o petycjach.

\section{Kwestie, które ekspert uznaje za istotne w związku z petycją}

Zgodnie $\mathrm{z}$ tezą przedstawioną w petycji obowiązująca transpozycja art. 168 lit. a dyrektywy jest wadliwa. Wnioskodawca wskazuje bowiem, że w art. 168 lit. a dyrektywy VAT prawodawca unijny użył słowa „zapłaconego”, co wskazywać ma na to, że prawo podatnika do obniżenia podatku należnego o kwotę podatku naliczonego powinno być możliwe dopiero od chwili, w której należność wynikająca z otrzymanej faktury zostanie zapłacona. Zdaniem Wnioskodawcy, aby transpozycję art. 168 lit. a dyrektywy VAT uczynić poprawną, potrzebna jest zmiana wielu przepisów ustawy o podatku od towarów i usług. Najpoważniejsza dotyczyć ma art. 86 ust. 2 pkt 1 u.p.t.u. Przepis ten, zdaniem Pytającego, powinien brzmieć następująco: Kwotę podatku naliczonego stanowi suma kwot podatku wynikajacych z zapłaconych faktur, otrzymanych przez podatnika...

Przechodząc do merytorycznej oceny proponowanych zmian, należy zauważyć, że art. 168 lit. a dyrektywy VAT wskazuje, że jeżeli towary i usługi wykorzystywane są na potrzeby opodatkowanych transakcji podatnika, podatnik jest uprawniony w państwie członkowskim, w którym dokonuje tych transakcji, do odliczenia od kwoty VAT, którą jest zobowiązany zapłacić, m.in. VAT należnego lub zapłaconego w tym państwie członkowskim od towarów i usług, które zostały mu dostarczone lub które mają być mu dostarczone przez innego podatnika. Natomiast art. 167 dyrektywy VAT określa właściwy moment powstania 
prawa do odliczenia. Prawo do odliczenia powstaje w momencie, gdy podatek, który podlega odliczeniu, staje się wymagalny. Zdarzenie powodujące powstanie obowiązku podatkowego ma miejsce, a VAT staje się wymagalny w momencie dostarczenia towarów lub wykonania usług (art. 63 dyrektywy VAT).

Zgodnie z polskimi regulacjami w zakresie, w jakim towary i usługi są wykorzystywane do wykonywania czynności opodatkowanych, podatnikowi przysługuje prawo do obniżenia kwoty podatku należnego o kwotę podatku naliczonego, przy czym kwotę podatku naliczonego stanowi m.in. suma kwot podatku wynikających z faktur otrzymanych przez podatnika (art. 86 ust. 2 pkt 1 u.p.t.u.).

Zasady odliczania podatku naliczonego związane są ściśle z momentem powstania obowiązku podatkowego w podatku od towarów i usług u wystawcy faktury. Prawo do obniżenia kwoty podatku należnego o kwotę podatku naliczonego u nabywcy powstaje, co do zasady, w rozliczeniu za okres, w którym w odniesieniu do nabytych lub importowanych przez podatnika towarów i usług powstał obowiązek podatkowy (art. 86 ust. 10 u.p.t.u.). Obowiązek podatkowy powstaje, co do zasady, z chwilą dokonania dostawy towarów lub wykonania usługi (art. 19a u.p.t.u.). Podatnik jest obowiązany odpowiednio udokumentować czynności podlegające opodatkowaniu, m.in. musi wystawić fakturę dokumentującą sprzedaż dokonaną przez niego na rzecz innego podatnika tego podatku.

W związku z powyższym, aby u podatnika powstało prawo do obniżenia podatku należnego o podatek naliczony, muszą być spełnione dwie przesłanki. Po pierwsze, u wystawcy faktury powstał obowiązek podatkowy z tytułu dostawy towarów lub świadczenia usług, po drugie, nabywca otrzymał fakturę dokumentującą tę transakcję.

Orzecznictwo Trybunału Sprawiedliwości Unii Europejskiej potwierdza stanowisko, że powstanie prawa do odliczenia podatku naliczonego nie może być uzależnione od okoliczności zapłaty wynagrodzenia należnego za daną dostawę. Jak wskazano w wyroku z 28 lipca 2010 r. ${ }^{2}$ : Trybunał już wielokrotnie podkreślat, [że] prawo do odliczenia stanowi integralna część mechanizmu podatku VAT i co do zasady nie może być ograniczane. W szczególności prawo to wykonywane jest natychmiastowo w odniesieniu do całości podatku naliczonego na poprzednich etapach obrotu. [...] Zgodnie z art. 63 tej dyrektywy, podatek staje się wymagalny $w$ momencie dostarczenia towarów lub wykonania usług, to znaczy w chwili wykonania danej transakcji niezależnie od tego, czy zostało już zapłacone wynagrodzenie za tę transakcję. W związku z tym podatek VAT należy się skarbowi państwa od dostawcy lub usługodawcy nawet wówczas, gdy nie otrzymał on jeszcze od swojego klienta zapłaty za dokonana transakcję. W podobny sposób art. 167 dyrektywy 2006/112 stanowi, że prawo do odliczenia powstaje $w$ momencie, gdy

2 Wyrok TSUE z 28 lipca 2011 r., sygn. akt C-274/10, Komisja Europejska vs Republika Wegierska; ZOTSiS 2011/7B/I-7289-7332, https://eur-lex.europa.eu/legal-content/ PL/ALL/?uri=CELEX:62010CJ0274 [dostęp 18 lutego 2019 r.]. 
podatek, który podlega odliczeniu, staje się wymagalny, co ma miejsce na podstawie art. $63 \mathrm{w}$ chwili wykonania transakcji, niezależnie od tego czy doszło do zapłaty za tę transakcję. Ponadto $w$ art. 168 lit. a) tej dyrektywy wyraźnie wskazano, $\dot{z}$ e prawo do odliczenia podatku naliczonego, z którego korzysta podatnik dotyczy nie tylko zapłaconego przez niego podatku VAT, ale także podatku VAT należnego. $Z$ treści art. 179 tej dyrektywy wynika również, że prawo do odliczenia wykonuje się zasadniczo poprzez potracenie od kwoty podatku należnego za dany okres rozliczeniowy kwoty podatku VAT, w stosunku do której powstało prawo do odliczenia $w$ trakcie tego okresu (zob. podobnie wyrok $z$ dnia 8 maja 2008 r. w sprawach połaczonych C-95/07 i C-96/07, Zb. Orz. s. I-3457, pkt 41).

$Z$ powyższego wynika, że zgodnie $z$ systemem ustanowionym przez dyrektywę 2006/112, wymagalność podatku VAT, a także powstanie i wykonywanie prawa do odliczenia nie sa co do zasady zależne od tego, czy należne za dana transakcje wynagrodzenie obejmujace podatek VAT zostało już zapłacone. Ocene te potwierdzaja pozostałe przepisy tej dyrektywy, zgodnie $z$ którymi rzeczywista zapłata wynagrodzenia może mieć wpływ na wymagalność lub możliwość odliczenia podatku VAT tylko w szczególnych okolicznościach wyraźnie przewidzianych przez rzeczona dyrektywę.

Polskie regulacje ustawy o podatku od towarów i usług w zakresie, w jakim ustalają zasady dotyczące powstania prawa do obniżenia podatku należnego o kwotę podatku naliczonego wynikającego $\mathrm{z}$ otrzymanych faktur, są więc zgodne z treścią odpowiednich przepisów dyrektywy VAT. W obydwu przypadkach $\mathrm{z}$ reguły wystawienie faktury przez sprzedawcę następuje $\mathrm{w}$ momencie powstania obowiązku podatkowego bądź też potwierdza zdarzenie powodujące wymagalność VAT, z zachowaniem wyją̧tków przewidzianych przez prawodawcę.

Dodatkowy warunek, czyli dokonanie zapłaty za nabyte towary lub usługi, stanowi realizację uprawnienia państw członkowskich wynikającego z treści art. 167a dyrektywy VAT. Państwa członkowskie mogą postanowić w ramach fakultatywnego systemu, że prawo do odliczenia przysługujące podatnikowi, którego VAT staje się wymagalny wyłącznie zgodnie z art. 66 lit. b, zostaje odroczone do czasu zapłacenia VAT od dostarczonych mu towarów lub wykonanych na jego rzecz usług swemu dostawcy lub usługodawcy.

Taki system został przewidziany dla tzw. małych podatników. Małym podatnikiem jest, zgodnie $\mathrm{z}$ art. 2 pkt 25 u.p.t.u., podatnik podatku od towarów i usług: - u którego wartość sprzedaży (wraz z kwotą podatku) nie przekroczyła w poprzednim roku podatkowym wyrażonej w złotych kwoty odpowiadającej równowartości 1200000 euro,

- prowadzący przedsiębiorstwo maklerskie, zarządzający funduszami inwestycyjnymi, zarządzający alternatywnymi funduszami inwestycyjnymi, będący agentem, zleceniobiorcą lub inną osobą świadczącą usługi o podobnym charakterze, $\mathrm{z}$ wyjątkiem komisu - jeżeli kwota prowizji lub innych postaci wynagrodzenia za wykonane usługi (wraz z kwotą podatku) nie przekroczyła 
w poprzednim roku podatkowym wyrażonej w złotych kwoty odpowiadającej równowartości 45000 euro.

Mały podatnik może wybrać metodę rozliczeń polegającą na tym, że obowiązek podatkowy w odniesieniu do dokonywanych przez niego dostaw towarów i świadczenia usług powstaje $\mathrm{z}$ dniem otrzymania całości lub części zapłaty po uprzednim pisemnym zawiadomieniu naczelnika urzędu skarbowego (art. 21 ust. 1 u.p.t.u.). Prawo obniżenia kwoty podatku należnego o kwotę podatku naliczonego w odniesieniu do nabytych przez małego podatnika towarów i usług, w okresie stosowania przez niego metody kasowej, powstaje nie wcześniej niż w rozliczeniu za okres, w którym podatnik dokonał zapłaty za te towary i usługi (art. 86 ust. 10e u.p.t.u.).

\section{Wnioski}

Zmiana przepisów ustawy o podatku od towarów i usług proponowana w petycji nie byłaby zgodna z regulacjami dyrektywy VAT. Obecnie obowiązująca transpozycja art. 168 lit. a dyrektywy VAT do polskiego systemu podatkowego - wbrew twierdzeniom Wnioskodawcy - nie jest wadliwa. Należy przychylić się do stanowiska ugruntowanego w orzecznictwie zarówno unijnym, jak i krajowym, że ogólne prawo do odliczenia podatku naliczonego nie może być uzależnione od okoliczności zapłaty wynagrodzenia należnego za daną dostawę. Prawo podatników do odliczenia od podatku, który są zobowiązani zapłacić, podatku naliczonego z tytułu towarów i usług otrzymanych przez nich stanowi zasadę podstawową wspólnego systemu podatku VAT ustanowionego przez ustawodawcę Unii Europejskiej. Prawo to, co do zasady, nie podlega ograniczeniu i przysługuje natychmiast w stosunku do całego podatku obciążającego transakcje powodujące naliczenie podatku.

System odliczeń ma bowiem na celu całkowite uwolnienie przedsiębiorcy od ciężaru podatku VAT należnego lub zapłaconego w ramach jego całej działalności gospodarczej. Wspólny system podatku VAT gwarantuje w ten sposób w zakresie ciężaru podatku neutralność wszystkich rodzajów działalności gospodarczej - niezależnie od jej celu lub wyników - pod warunkiem że co do zasady ona sama podlega opodatkowaniu podatkiem VAT .

3 Wyrok TSUE z 21 czerwca 2012 r., sygn. akt C-80/11, Mahagében kft v. Nemzeti Adóés Vámhivatal Dél-dunántúli Regionális Adó Fơigazgatósága i Péter Dávid v. Nemzeti Adó- és Vámhivatal Észak-alföldi Regionális Adó Főigazgatósága; ZOTSiS 2012/6/I373, http://curia.europa.eu/juris/document/document.jsf?text=\&docid=124187\&pag eIndex $=0 \&$ doclang $=$ PL\&mode $=1$ st $\&$ dir $=\&$ occ $=$ first $\&$ part $=1 \&$ cid $=14364382$ [dostęp 18 lutego 2019 r.]. 